\title{
METAPHORS AND METAPHORICAL LANGUAGE/S IN RELIGION, ART AND SCIENCE
}

\begin{abstract}
Languages play an essential role in communicating aesthetic, scientific and religious convictions, as well as laws, worldviews and truths. Additionally, metaphors are an essential part of many languages and artistic expressions. In this paper I will first examine the role metaphors play in religion and art. Is there a specific focus on symbolic and metaphoric language in religion and art? Where are the analogies to be found in artistic metaphors and religious ones? How are differences to be described? How do various (philosophical) concepts of aesthetics and theological concepts explain those different kinds of language and how, if at all, do they make use of them? Lastly: what could be added to aesthetics, philosophy and theology by examining carefully the role and importance of language, including nonverbal, sign language and especially metaphorical language? Without the human capacity for language, religions are scarcely imaginable. A widening of traditional exegesis and hermeneutics by taking into account nonverbal semantics is needed. Religion is a cognitive and linguistic phenomenon. By taking this seriously, we set and enable an agenda to discuss religion scientifically, leaving aside for the purpose of a scientific understanding and discourse about the inter-religious and the inner-religious claims of truth and absolutist claims. To sum it up: metaphor is introduced as an important means of language when it comes to religious conceptualization. Next, I will show that art, more than religion, deals with visual metaphor - the latter being an image that suggests a particular association, similarity or analogy between two (or more) generally unconnected visual elements. This often, but not always, functions in a roughly comparable fashion to the better-known concept of verbal metaphor. In addition, visual metaphor has developed many original and unique characteristics. These two sections are followed by another one dealing with (inter)cultural philosophy of religion and aesthetics, as well as the meaning of metaphors for these disciplines. The next section is on metaphor and metaphorical language in mathematics, natural sciences and art and how they are related, i.e. influence and help each other. I will discuss the critical approach to metaphors in natural science and provide a short introduction to the cultural history of mathematics and art. Mathematicians and artists have long been on the quest to understand the physical world they see before them and the abstract objects they know by thought alone. How have art and mathematics helped each other in representing each other's concepts? A final section provides a summary and an outlook: theology is contextual as is science - and so is art. All these disciplines partly rely upon metaphor and by the help of metaphor get
\end{abstract}


closer to an intercultural and interdisciplinary understanding. I shall argue that, by dealing more carefully with their metaphorical language and their own metaphors, together they become better equipped to map the world.

Keywords: metaphor; metaphorical language; cognitive science; neurobiology; theology; hermeneutics; intercultural philosophy; interdisciplinary discourse

1. Introduction. 2. Language, signs and metaphors. 3. Metaphors and metaphorical language in religion - theological outcomes and implications. 4. Metaphors and metaphorical language in art - aesthetics re-acting. 5. (Inter)cultural philosophy of religion and aesthetics. 6. Metaphors in natural science (and art). 7. An interdisciplinary (intercultural) approach to "map" the world a summary and outlook.

\section{INTRODUCTION}

Is there a mutual relation between natural sciences, philosophy and theology? Despite the controversies, there is a general consensus among researchers to seek a common platform for dialogue to build a coherent view of the world. But what areas are involved in such a dialogue and what might be its outcomes and perspectives?

As a theologian and philosopher (of religion), in this paper I would like to examine the inner - and interdisciplinary outcomes and perspectives that result when theologians, philosophers, mathematicians, artists and scientists discuss the role of metaphor and metaphorical language/s in their respective fields. Is there a chance that metaphors function as "bridge builders" between them, as "tools of interdisciplinary hermeneutics", so to speak?

\section{LANGUAGE, SIGNS AND METAPHORS}

First of all, we have to remember that language and languages play an essential role in communicating aesthetic, scientific and religious truths, as well as laws and regulations. We are therefore well advised to interpret and understand the language(s) of the aesthetic, scientific and religious systems we want to communicate with for the sake of a mutual understanding. In doing so, we must also deal with signs, 
symbols and metaphors which play a constitutive role in their different languages. On the other hand, if we want to be understood interconfessionally, interreligiously, interculturally and interdisciplinary, we have to try hard to learn more about our own language system(s) and be aware of their shortcomings and blind spots as well as the inherent causes of misunderstanding. We should also try to develop them in order to be better understood by those who are not genuinely familiar with our beliefs, thoughts and discipline, i.e. our linguistic specialities expertise and its specific contextual elements.

Let us take metaphors here as a form of pictorial representation, which conveys a new and important message or "truth" in a context of meaning different from the original one. Symbols on the other hand always represent the same thing and convey the same meaning or truth. Carl Jung's ideas on symbols, for example, relate to his notion of archetypes. In this sense, symbols are culturally specific but also deeply personal.

"The differences between a metaphor and a symbol in art is demonstrated by comparing a pair of paintings. Sandro Botticelli painted La Primavera in 1482, while Hans Holbein the Younger painted The Ambassadors in 1533. La Primavera is ostensibly about spring using a cast of mythological beings. The Ambassadors, on the other hand, is about a meeting between Jean de Dinteville and Georges de Selve. On the surface La Primavera provides like for like substitutions of mythological figures for spring. It also may hark back to ideas concerning the blossoming of the whole world and the Garden of Eden. Others, such as Marsilio Ficino, see it as a metaphor for neoplatonic love. The difference between a metaphor and a symbol here is that the whole painting is one metaphor or allegory. The Ambassadors uses symbols to provide additional information concerning who the figures are and the story behind their meeting. It does not attempt to tell a second story, but to provide additional information. For example, the lute next to Georges de Selve's knee is a symbol of peace, but the cord is broken to symbolize discord. 
Metaphors can form parts of narrative. A long metaphor is known either as an extended metaphor or as an allegory. Films, poems and novels can include symbols, but only metaphors are used as a narrative device. Sometimes entire films, poems and novels are metaphors."

In addition to that, it is important to remember, especially for hermeneutics (of religion), that the word "symbol" has its roots in the Greek word symballein ("to throw together"). More specifically, in Christianity a symbol sometimes "represents" the intertwining of human and divine, of material and non-material - coming close to the meaning and role sacraments play in liturgy and theology.

As for signs - sometimes also called symbols in a narrow sense they are often graphical presentations. The main difference being that a sign is a language of its own and specifically meant to communicate certain information. To sum it up: signs are usually informative, regulatory, warning or prohibitory. A sign ought to be followed as it is. Therefore, many signs have a universal meaning shared by people from various backgrounds.

To the contrary, a symbol " $\ldots$ is a something that is accepted by certain group of people or general population. It can be interpreted differently by people from different backgrounds. A cross is an example of symbol that has been universally accepted as representing Christianity." This means that a symbol is the form of a sign that may have deep meaning. It can be interpreted in different ways since its meaning may not be universally shared by different people.

Let us now once more get back to metaphors and their close relation to simile and analogy. A different definition of metaphor is that it is a figure of speech that uses one thing to mean another and makes a comparison between the two. A simile, which can be

1 M. Wollacott, What Is the Difference between a Metaphor and a Symbol?, (https://www. wisegeek.com/what-is-the-difference-between-a-metaphor-and-a-symbol.htm), [accessed 09/2020].

2 M. Trevor, Difference between Sign and Symbol, (http://www.differencebetween.net/ miscellaneous/difference-between-sign-and-symbol/), [accessed 09/2020]. 
defined as one type of metaphor, compares two different things in order to create a new meaning. "An analogy is comparable to metaphor and simile in that it shows how two different things are similar, but it's a bit more complex. Rather than a figure of speech, an analogy is more of a logical argument. The presenter of an analogy will often demonstrate how two things are alike by pointing out shared characteristics, with the goal of showing that if two things are similar in some ways, they are similar in other ways as well. A metaphor carries so much more power than a simile, because it's direct. Using 'like' or 'as' to make an open comparison will often diminish the vivid visual you're trying to paint in the reader's mind. Likewise, a spot-on metaphor will spark instant understanding for a reader, without the elaboration that an analogy requires." ${ }^{3}$

It seems that, because of their rather strong subjectivity or even "otherworldliness" symbols and symbolic language in a broader sense are particularly difficult to interpret when it comes to promoting a mutual understanding between science, religion and art, to compare and understand better their explanations of the world. On the other hand, in natural science or mathematics we find many signs, some of them close to analogies and metaphors, but almost no symbols (unless we use the term in its narrow sense introduced above, which makes "symbol" analogous with the term "sign").

If we want to get as close as possible to using similar concepts and explanations of the world in religion/theology, art/aesthetics and natural science/mathematics, we are therefore well advised to conform to their use of metaphors and investigate how they are used and what they mean in religion, art and science/s.

3 B. Clark, Metaphor, Simile, and Analogy: What's the Difference?, (https://copyblogger. com/metaphor-simile-and-analogy-whats-the-difference/), [accessed 09/2020]. 


\section{METAPHORS AND METAPHORICAL LANGUAGE IN RELIGION - THEOLOGICAL OUTCOMES AND IMPLICATIONS}

I shall now examine the role metaphors play in religion: is there a specific focus on symbolic and, for our purposes, metaphoric language in it?

As argued in the first section, it is quite clear that without the human capacity for language, religions are scarcely imaginable. On the one hand it has become clearer and clearer that traditional exegesis and hermeneutics need to take into account nonverbal semantics. The use of non-textual and nonverbal sources can promote and facilitate intercultural exchange. On the other hand, metaphorical language has become increasingly more important in order to understand the "mechanisms" of religious narratives and rituals. Therefore, religion - at least to a certain extent - is a cognitive-linguistic phenomenon. This enables an interdisciplinary agenda for a scientific debate on religion, leaving aside inter-religious and inner-religious claims of truth and absolutist claims.

Linguistics (which I take to belong to natural science) exists externally as bodily and linguistic practices and internally as experiences, mental operations, and emotions in the mind-brain, “...interacting internally in a complex relationship and externally with other brain-minds, often but not always in particular spatial and social settings." In this respect religion can be understood as a product of the human mind. Therefore, a cognitive-linguistic anthropology of religion is needed, not least to explain religious rituals and give a cognitive and linguistic account of them. On the other hand, natural science and religion are getting rather close - this is a starting point for a better interdisciplinary understanding.

4 Religion, Language and the Human Mind, eds. P. Chilton, M. Kopytowska, Oxford University Press, New York 2018, xvii. 
This is particularly important as (intercultural) theology is more and more interested not only in social and cultural history, hermeneutics and anthropology, but also in the human brain (as studied in neuroscience) and human consciousness (as studied in cognitive science). Therefore, metaphor is and has to be introduced as an important linguistic tool when it comes to religious conceptualization.

\section{METAPHORS AND METAPHORICAL LANGUAGE IN ART - AESTHETICS RE-ACTING}

Art, more than religion, deals with visual metaphor - the latter being “... an image that suggests a particular association, similarity or analogy between two (or more) generally unconnected visual elements. This often functions in a roughly comparable fashion to the better-known concept of verbal metaphor, but not always, and visual metaphor has developed many of its own unique characteristics. This 'presence', whether 2D, 3D, filmic or whatever, is primarily optical. It is a nonverbal embodiment of a conceptual metaphor. As Noël Carroll describes it, visual metaphors 'prompt insights' in the viewer by depicting 'noncompossible' (generally impossible to combine) elements in a 'homospatially unified' image." ${ }^{5}$

It follows from this that optical tropes should be understood as having a heuristic value in themselves, rather than as representations of a previously unknown entity, for example a deity, etc. "In cognitive metaphor theory, this would be described as an imagistic target compared pictorially to some visual thing from another category, the source. (In I.A. Richards's language, the tenor and vebicle, respectively.)" 6 The formal, technical and stylistic aspects become

5 M.S. Brandl, Dr Great Art Episode 42: Defining of Visual Metaphor, (http://brandl-art-articles.blogspot.com/2018/09/dr-great-art-episode-42-defining-of.html), [accessed 09/2020].

6 Ibid. 
as important as pictorial, representational images. Visual tropes can be seen as a thought process, involving the fact that metaphors are embodied. "The discovery animating all of this is that trope is the basis of thought, thus language is one instance of it, not the other way round."

By using these insights from aesthetic metaphor theory in practical and systematic theology, we could for example gain a new and better understanding of the Eucharist. Let us take the "function of the Eucharist" as a sort of "metaphorical game" that can help us to "playfully" learn about the Reign of God. We then realize that in ritualized movements, the setting of the altar, the elevation of bread and wine, etc., we have a means for the theologically, philosophically (and aesthetically) untrained person to "experience" what a long, theoretical explanation would call a "real presence" and, inclusively, the trinitarian doctrine and certain aspects of the doctrine of the two natures. The eucharist then becomes, to a certain extent, "understandable" to lay persons and even to non-Christians and nonbelievers. In general, "noncompossible" elements which constitute a sacramental event become "metaphorically understandable" in a "homospatially unified" image.

If visual tropes (and embodied metaphors) can be seen as a thought process, some "religious mysteries", which so far seemed to be best explained by paradoxical language, could be "understood" by artistic visualization followed by aesthetic and theological interpretation.

The artistic, nonverbal embodiment of a conceptual metaphor (and art in general) could therefore not only help "prompting insights" in the viewer by depicting "noncompossible" elements in a "homospatially unified" image, but art could also function as a "bridge builder", enabling religion by representing a previously unknown entity (symbol), a deity for example, and helping theology to "explain" religious insights and/or convictions to the secular mindset and to 
people from other cultural and religious backgrounds (metaphor). The possibility to improve the mutual understanding between church and world, religion and religion and theology, philosophy and science is growing.

\section{5. (INTER)CULTURAL PHILOSOPHY OF RELIGION AND AESTHETICS}

Intercultural philosophy takes culture and intercultural exchange seriously when it comes to questions of the ultimate reality or the final truth and global ethics. Here I use the term 'intercultural philosophy' to characterize a specific philosophical tradition which explicitly considers different philosophical cultures ("interculturality").

There are three main lines of arguments - with different methodological, empirical, scientific and epistemological problems and a specific terminology: (1) with a strong comparative element, closely connected with the search for an intercultural hermeneutics and "cultural overlapping"; (2) with a strong emphasis upon the history of philosophy, pointing out the different "birth places" of philosophy; and (3) the one trying to interculturally transform philosophy. ${ }^{8}$

Intercultural philosophy started between the end of the 1980s and the beginning of the 1990s, partly as a reaction against economic and political globalization and its tendency to unify cultures; and partly as a reaction against the rise of cultural conflicts and the so-called "clash of civilization".

Philosophy and theology had to recognize the contextuality of thought and belief and to deal anew with the question whether this excludes universal truths and universality. This led to a search for "transcultural overlapping" and a transcendental and transcultural

8 R.A. Mall, Essays zur interkulturellen Philosophie, T. Bautz 2003, 39-43

9 S.P. Huntington, The Clash of Civilizations and the Remaking of World Order, Simon and Schuster, New York 1996. 
philosophy or theology, i.e. philosophy of religion - a branch of interreligious and pluralist theology.

The expression "Verleichende Religionswissenschaft" (comparative religious studies) was first used for a merely secular and phenomenological, i.e. epistemological, approach; its comparative aspect was taken up especially by what has recently developed as comparative theology, which distinctively stresses its Christian heritage. In some pluralist or interreligious theologies the possibility of a "neutral scientific" access is seriously doubted. This, however, does not lead comparative theologians towards a transcultural model (see above).

Klaus von Stosch, a comparative theologian, states: „Es geht der komparativen Theologie nicht um Allgemeinaussagen über die Wahrheit einer oder mehrerer Religionen, sondern um das Hin und Hergehen zwischen konkreten religiösen Traditionen angesichts bestimmter Problemfelder, um Verbindendes und Trennendes zwischen den Religionen neu zu entdecken." ${ }^{10}$ The issue here is to bind together the truth claim of one's own faith with a respectful appreciation of other religions. „Das religionstheologische Urteil wird gleichsam aufgeschoben, um der Bewährung im Einzelfall bzw. in vielen Einzelfällen Platz zu machen." ${ }^{11}$ The recent debate between a so-called pluralist or interreligious theology and a comparative or intercultural theology or philosophy is also a debate about different ways to emphasize commonalities and differences, a truth which is undividable and absolute or rather manifold and "in the making".

I prefer the term intercultural theology or intercultural philosophy in order to avoid any metaphysical and absolutist claim - by way of providing a definition, independently of any missiological or

10 K. von Stosch, Komparative Theologie - ein Ausweg aus dem Grunddilemma jeder Theologie der Religionen?, 9, (https://kw.uni-paderborn.de/fileadmin/fakultaet/Institute/ kath-theologie/Systematische_Theologie/Prof._Dr._Klaus_von_Stosch/Publikationen/3._Artikel_Articles/4._Komparative_Theologie.pdf) [accessed 09/2020].

11 F. Eissler: Komparative Theologie - Eine Alternative zu bisherigen religionstheologischen Konzepten?, (http://www.reformiert-info.de/7918-0-56-7.html) [accessed 09/2020]. 
inclusivist approach. In the sense used here "inter" characterizes a discursive approach towards reality and truth yet to be achieved, aimed at establishing a (non-Eurocentric) dialogue between different cultures and philosophical positions. This is not meant "to correct a postmodern fragmentation of reason", to overcome a cultural relativism based upon a more isolationist understanding of culture, or to create a synthesis of philosophical traditions. Rather, the task of "mediating" between cultures and traditions and their "unique" terminologies, questions and solutions is to be understood in a dialectic, not metaphysical sense. I suggest to start from an open concept of reason, since my view is that every reasonable approach is also dependent on context, situation and individuality. ${ }^{12}$

Once again, art can be very helpful here as a bridge-builder or intermediator. In addressing religious topoi explicitly or implicitly, sometimes even different ones in the same painting, an "aesthetic dialogue" takes place and the "unity of diversity" is getting a new sense and metaphorical meaning. Art does not create metaphysical synthesis since aesthetically it always only suggests, neither does it stick to fragmentation since it aims at a (pictorial) "composition".

Intercultural philosophy of religion and aesthetics then use metaphors and metaphorical language in art to improve metaphorical meaning and explanation with respect to the topoi of interreligious, intercultural and interdisciplinary dialogue.

\section{METAPHORS IN NATURAL SCIENCE (AND ART)}

Let us now ask whether there is something like (symbolic and/or) metaphorical language in natural science and, if so, how it works.

12 H.R. Yousefi, Interkulturalität. Eine interdisziplinäre Einführung, WBG, Darmstadt 2011; H.R. Yousefi, Grundbegriffe der Interkulturellen Kommunikation, UTB, München 2014. 
There is a critical discussion of metaphors in the cultural history of mathematics and art. ${ }^{13}$

Mathematicians, natural scientists and artists have long been on a quest to understand the physical world they see before them and the abstract objects they know by thought alone. But is there a chance for them to understand each other's concepts, especially with the help of metaphors?

Lynn Gamwell points out the important ways mathematical concepts have been expressed by artists. ${ }^{14}$ After describing mathematics from Antiquity to the Enlightenment, she focuses on modern culture and shows that self-reflection is a central aspect of both modern mathematics and art. She argues that this common introspective element highlights a deep resonance between the two fields. She further shows how mathematical ideas are embodied in the visual arts, citing cases such as David Hilbert's meaning-free signs, Aleksandr Rodchenko's monochrome paintings, Kurt Gödel's questions about the nature of mathematics and Jasper Johns' questions concerning the nature and purpose of art. ${ }^{15}$

Mathematics and art complement each other with respect to terminology and method. Compared to art, mathematics is much better known for its symbolic language. However, we also find a special use of metaphors in mathematics. With respect to mathematics and art we suggest a method close to the method for intercultural philosophy and theology suggested earlier: namely, to use metaphorical language in a dialectic, not metaphysical sense in

13 J. Forsey, Metaphor and Symbol in the Interpretation of Art, (http://www.artsrn.ualberta. ca/symposium/files/original/ff2c58ca6f0977066bdfb96433c52769.PDF), [accessed 09/2020].

14 L. Gamwell, Mathematics and Art: A Cultural History, Princeton University Press, Princeton 2016.

15 J. Johns, Writings, Sketchbook Notes, Interviews, Museum of Modern Art, New York 1996; K. Gödel, Band 1: Philosophie I, Maximen 0 - Volume 1: Philosophy I, Max 0, in: Philosophische Notizbücher - Philosophical Notebooks, ed. E.-M. Engelen, De Gruyter, Berlin - München - Boston 2019. 
order to establish a dialectical discourse between art and mathematics about the world and reality. As for natural science, we suggest once again to start from an open concept of reason and a rational approach dependent on context, situation and individuality. We are thus well advised to integrate methodologically what is known as the "observer's standpoint" in natural science with what could and should be called the "hermeneutics of natural science".

I shall now give an example to illustrate how metaphors in art and natural science widen their horizon, enable them to explain a deeper insight, make them more understandable in interdisciplinary discourse and, lastly, how the encounter with the Other reforms each discipline to a certain and sometimes unexpected extent.

The language of science is often metaphorical and analogical to make sense of scientific phenomena and disseminate its findings to the wider scientific community and the general public. It is therefore especially important for scientists, science communicators, and science educators to acknowledge the conceptual, social and political dimensions of metaphors in science and adopt a critical perspective on their use and effects - metaphors here are not just seen as heuristic and rhetorical devices, but also as social and political "messengers" rooted in cultural dynamics and power relations. ${ }^{16}$

This is especially true of life sciences. Lakoff and Johnson have introduced the theory of conceptual metaphor: the nature of human cognition is metaphorical and all knowledge emerges as a result of embodied physical and social experiences. ${ }^{17}$

Metaphors are thus much more than mere linguistic embellishments. They are the foundation of thought processes and conceptual understandings aimed to map meaning from one knowledge and/or

16 C. Taylor, B.M. Dewsbury, On the Problem and Promise of Metaphor Use in Science and Science Communication, Journal of Microbiology and Biology Education 19(2018)1, (DOI: https://doi.org/10.1128/jmbe.v19i1.1538).

17 G. Lakoff, M. Johnson, Metaphors We Live By, University of Chicago Press, Chicago 1980. 
perceptual domain to another. When attempting to make sense of abstract, intangible phenomena, we draw from embodied experiences and look at concrete entities to serve as cognitive representatives. For example, in the classic trope "time is money", money is the source domain, time the target domain. The trope urges us to conceptualize time as a form of currency that can be spent, invested, valued and/ or wasted.

Because humans are not very good in interpreting macrocosmic and microcosmic phenomena, they rely on metaphors grounded in 'mesocosmic' experiences. A good example being Robert Hooke's description of a "cell" when the image of a piece of cork under his microscope reminded him of cells in a monastery. Another example is Kepler's account of planetary motion developed through a comparison with a clock.

Metaphors are criticized for being ambiguous and imprecise. Their general potential cannot however be ignored. (Although we also need to consider a misuse or, more generally, a "falsification" of traditional metaphors by recent scientific research.)

\section{AN INTERDISCIPLINARY (INTERCULTURAL) APPROACH TO “MAP" THE WORLD - A SUMMARY AND OUTLOOK}

Is there a better interdisciplinary understanding of the special languages and metaphors employed by different disciplines, such as art/aesthetics, religion/theology and natural sciences/mathematics? Where are the analogies to be found in artistic metaphors and religious ones? How are the differences to be described? Are there metaphors essentially belonging to natural sciences or mathematics? Or are they merely referring to the subjective elements of introspection and "translating" them into daily life?

As we have seen above, according to Noël Carroll visual metaphors 'prompt insights' by depicting "noncompossible" (generally impossible to combine) elements in a "homospatially unified" image. We have 
also seen that there are close analogies between metaphors used in art and mathematics. And we know that there is a challenging and sometimes misleading use of mesocosmic metaphors in natural sciences, especially life sciences. (And we also had a quick look at how some mathematical ideas are embodied in the visual arts.)

As for religion, something similar is the case when theology has to deal with complicated dogmatical structures. They too can be better "understood" with the help of (artistic) metaphors. Antonio Barcelona, for example, works on metaphor and metonymy in language and art and the dogma of the Holy Trinity and its artistic representation. ${ }^{18}$ Mihailo Antonović analyzes the metaphor of the "struggle against oneself" as elaborated in the classic Christian Orthodox book Unseen Warfare, tracing the cognitive, ontological and, for believers, metaphysical origins of the many metaphors occurring in Orthodox Theology. ${ }^{19}$ Paul Clinton and David Cram concentrated on the dogma of the Eucharist and formulated new and innovative interpretations of the hoc est corpus through a cognitive analysis of the liturgical language involved in its celebration. With the help of modern deictic space theory, the hoc is investigated more closely than the 'body'. This opens new ways of understanding the meaning of 'real presence'.

If religion, as stated above, is also a cognitive and linguistic phenomenon and if therefore metaphorical language can advance a scientific understanding of religion on an intercultural and interdisciplinary level (leaving aside claims of truth and absolutist claims), religion is thereby understood as a product of the human mind, thus introducing a cognitive-linguistic anthropology of religion. Furthermore, a "religion in the brain" is also introduced, i.e. the contribution of neuroscience to an explanation of religion.

18 Metaphor and Metonymy at the Crossroads: A Cognitive Perspective, ed. A. Barcelona, Mouton de Gruyter, Berlin - New York 2003.

19 M. Antonović, Waging war against oneself: A metaphor at the heart of Christian ascetic practice, in Religion, Language and the Human Mind, op. cit., 386-406. 
In the process of this discussion, theology is led towards a better understanding of the meaning of the sacraments, icons, etc. Similarly, a theology based upon linguistics and metaphor theory could suggest a religious understanding of the incarnation for the visual arts in order to deconstruct a purely materialistic understanding of reality and the world as in natural science(s).

The interdisciplinary discussion of metaphors and metaphor theory in mathematics and arts can add to this a pluri-disciplinary understanding of reality and the role human beings play in this world.

As we have seen, there is an ongoing interdisciplinary discussion of language (verbal and nonverbal) and metaphor theory in art and religion, involving aesthetics and theology as well as natural science/ mathematics and art. Such a discussion can help highlight analogies and important differences, leading to a better inter - and sometimes also interdisciplinary (and rational) understanding of each discipline's "efforts to map the world", to understand reality and sometimes also to get to a final truth.

"As argued by constructivists, social reality is to a large extent co-constructed by discourse." 20 Some things exist because we believe them to exist: the role of language here is to attribute functions and deontic powers, which might well be the key to the functioning of social institutions. Again, the "principle of falsification" becomes relevant in the sense that, besides all metaphysical discussions there is also a more empirical (let us also call it a more materialistic) and epistemological way of "mapping the world".

Therefore, I often speak of "verantwortete Vorläufigkeit" ("responsible interim") in hermeneutics and ethics - in this paper and other writings also in theology, aesthetics and natural science. This is paired with the suggestion to experimentally try and adjust "the principle of falsification" to theological and aesthetic methodology and may well lead to a new discussion of a de-ontological point of view I certainly

20 Religion, Language and the Human Mind, op. cit., 466. 
see in such a "responsible interim", i.e. a "metaphysical interim" and its roots in Kantian critical idealism.

We have already discussed the explanatory (and sociological) use of metaphors in natural sciences - the opportunities and risks they afford. And, as already shown, metaphors also exist in mathematics.

To conclude, let us now investigate whether there could be "ontic reasons" for such metaphors. Mathieu Aubry argues that analogies play an essential role in mathematics: "George Lakoff and Rafael E. Núñez have shown in Where Mathematics Comes From ${ }^{21}$ that our understanding of basic mathematics is deeply linked to our experience of the world. They claim that we understand mathematics through conceptual metaphors between source domains (for example spatial relationships between objects) and target domains (abstract mathematics). These metaphors are supposed to map certain basic schemata of thought, namely, cross-modal organizational structures. In fact the use of conceptual metaphor is a more general cognitive process, used not only in other sciences (as in physics or cell biology and ecology but also in every aspect of our understanding of the world, for example in philosophy and ethics."22 But Aubry is also "... dealing with specific cases of metaphors in advanced and abstract mathematics linked to our conception of space. The goal is both to show that conceptual metaphor theory continues to apply with great success in these areas, and to try to understand the theory more deeply."23

Let me give one example taken from Claes Johnson: "An equation in mathematics has the form $\mathrm{A}=\mathrm{B}$, where $\mathrm{B}$ is not identical to $\mathrm{A}$, because the equation $\mathrm{A}=\mathrm{A}$ is not interesting. Thus an equation $\mathrm{A}$

21 G. Lakoff, R. Núñez, Where Mathematics Comes From: How The Embodied Mind Brings Mathematics Into Being, Basic Books, New York 2003.

22 M. Aubry, Metaphors in Mathematics: Introduction and the Case of Algebraic Geometry, 1, (https://ssrn.com/abstract=1478871 or http://dx.doi.org/10.2139/ssrn.1478871), [accessed 09/2020].

23 Ibid. 
$=\mathrm{B}$ rather expresses something like $\mathrm{CA}=\mathrm{CB}$ where $\mathrm{C}$ is a shared aspect while $\mathrm{A}$ and $\mathrm{B}$ represent something which is different. The basic example is:

$$
2=1+1
$$

or:

$$
\text { whole }=\text { sum of parts (integral of parts per unit step) }
$$

like in:

position $=$ sum of increments of position $=$ integral of velocity velocity $=$ sum of increments of velocity $=$ integral of acceleration.

It is clear that 'he whole' as a non-subdivided unity (like 2) is something different than 'the sum of the parts' (like $1+1$ ) because the parts and the summation are visible/present in 'the sum of the parts' but not in 'the whole'. One can decompose 2 also as $2=0.5+$ 1.5. So 'the whole' and 'the sum of the parts' share something without being identical. So what do they share? Yes, they share the number associated with 'the whole' (that is 2) and the number associated with 'the sum of the parts' (that is also 2). Thus $1+1$ is exactly 'as big as' 2 , but $1+1$ carries an additional structure (parts and summation), which is not visible when looking merely on the size of $1+1$. So mathematical equations are metaphors, and is it then so, like in ordinary language, that an interesting equation (metaphor) tells us something of interest? Probably. About the tenor or the vehicle? It can probably go both ways, so that something unfamiliar in something familiar gets exposed, or that something unfamiliar is made more familiar." 24

"Something unfamiliar in something familiar gets exposed" - is that not also the case in many paintings, as well as in poetry and art in general? I am not saying that it is the only aspect and the goal of art, although very often art makes something unfamiliar more familiar

24 C. Johnson, Towards Understanding by Critical Constructive Inquiry: What is a Metaphor, in Mathematics?, 15 April 2010, (https://claesjohnson.blogspot.com/2010/04/what-is-metaphor-in-mathematics.html), [accessed 09/2020]. 
in a metaphorical way. The same is true for religious rites, parables and doctrines (e.g., the doctrine of the holy trinity or the twofold nature). Theology is contextual as is science - and all the more so is art. All these disciplines partly rely upon metaphor and with the help of metaphor get closer to an intercultural and interdisciplinary understanding. By dealing more carefully with their metaphorical language and their own metaphors, together they become better equipped to map the world.

\section{BIBLIOGRAPHY}

Antonović M., Waging war against oneself: A metaphor at the heart of Christian ascetic practice, in Religion, Language and the Human Mind, ed. P. Chilton, M. Kopytowska, Oxford University Press, New York 2018, 386-406.

Aubry M., Metaphors in Mathematics: Introduction and the Case of Algebraic Geometry, (http://dx.doi.org/10.2139/ssrn.1478871), [accessed 09/2020].

Barcelona A. (ed.), Metaphor and Metonymy at the Crossroads: A Cognitive Perspective, Mouton de Gruyter, Berlin - New York 2003.

Brand1 M.S., Dr Great Art Episode 42: Defining of Visual Metaphor, (http://brand1-art-articles.blogspot.com/2018/09/dr-great-art-episode-42-defining-of.html), [accessed 09/2020].

Chilton P., Kopytowska M. (eds.), Religion, Language and the Human Mind, Oxford University Press, New York 2018.

Clark B., Metaphor, Simile, and Analogy: What's the Difference?, (https://copyblogger. com/metaphor-simile-and-analogy-whats-the-difference/), [accessed 09/2020].

Eissler F., Komparative Theologie - Eine Alternative zu bisherigen religionstheologischen Konzepten?, ( http://www.reformiert-info.de/7918-0-56-7.html), [accessed 09/2020].

Forsey J., Metaphor and Symbol in the Interpretation of Art, (http://www.artsrn. ualberta.ca/symposium/files/original/ff2c58ca6f0977066bdfb96433c52769. PDF), [accessed 09/2020].

Gamwell L., Mathematics and Art: A Cultural History, Princeton University Press, Princeton 2016.

Gödel K., Band 1: Philosophie I, Maximen O - Volume 1: Philosophy I, Max 0, in: Philosophische Notizbücher - Philosophical Notebooks, ed. E.-M. Engelen, De Gruyter, Berlin - München - Boston 2019. 
Huntington S.P., The Clash of Civilizations and the Remaking of World Order, Simon and Schuster, New York 1996.

Johns J., Writings, Sketchbook Notes, Interviews, Museum of Modern Art, New York 1996.

Johnson C., Towards Understanding by Critical Constructive Inquiry: What is a Metaphor, in Mathematics?, 15 April 2010, (https://claesjohnson.blogspot. com/2010/04/what-is-metaphor-in-mathematics.html), [accessed 09/2020].

Lakoff G., Johnson M., Metaphors We Live By, University of Chicago Press, Chicago 1980.

Lakoff G., Núñez R., Where Mathematics Comes From: How The Embodied Mind Brings Mathematics Into Being, Basic Books, New York 2003.

Mall R.A., Essays zur interkulturellen Philosophie, T. Bautz 2003.

Stosch K. von, Komparative Theologie - ein Ausweg aus dem Grunddilemma jeder Theologie der Religionen?, (https://kw.uni-paderborn.de/fileadmin/fakultaet/ Institute/kath-theologie/Systematische_Theologie/Prof._Dr._Klaus_von_ Stosch/Publikationen/3._Artikel_Articles/4._Komparative_Theologie.pdf), [accessed 09/2020].

Taylor C., Dewsbury B.M., On the Problem and Promise of Metaphor Use in Science and Science Communication, Journal of Microbiology and Biology Education 19(2018)1, (DOI: https://doi.org/10.1128/jmbe.v19i1.1538).

Trevor M., Difference between Sign and Symbol, (http://www.differencebetween. net/miscellaneous/difference-between-sign-and-symbol/), [accessed 09/2020]. Wollacott M., What Is the Difference between a Metaphor and a Symbol?, (https:// www.wisegeek.com/what-is-the-difference-between-a-metaphor-and-a-symbol.htm), [accessed 09/2020].

Yousefi H.R., Grundbegriffe der Interkulturellen Kommunikation, UTB, München 2014.

Yousefi H.R., Interkulturalität. Eine interdisziplinäre Einfübrung, WBG, Darmstadt 2011.

Sybille C. Fritsch-Oppermann

Technische Universität Clausthal (Lecturer)

(Clausthal University of Technology, Germany)

sybillefritschoppermann@web.de

DOI: 10.21697/spch.2020.56.3.02 